Angel Cruchaga S. M.

\title{
El Viaje
}

I

ANZAMOS los aviones

en la loca conquista de los mundos.

Cantan las hélices dividiendo el día.

IIremos a las playas de Saturno!

De puerto en puerto.

en bahías de azul, en un crepúsculo que agonice allá lejos en los brazos de Jesucristo en horizontes de humo.

[Recuerdos de la tierra! plazas y torres en un cielo turbio. ¡Oh, lejanas montañas de amatisfa! Hemos levado el ancla del futuro...

iOh rumor de las hélices que derraman estrellas en el vuelo! Hasta el lejano mar quedó dormido. pero su canto lo llevamos dentro.

¿Hacia qué playa vamos? ¿Será la luna nuestro puerto? ¿O iremos a morir en una estrella que canta en el vacío como un ciego?... 


\section{¡Estábamos tan solos!}

La muerte nos corria por los huesos.

En un gesto de horror, nuestros aviones

en el cielo de Elias se perdieron.

Nada queda del mundo.

Rotas las vestiduras

sentimos en la carne los luceros.

El corazón es valle de luna.

Hemos subido tanto que nuestros ojos mirarán la túnica de Dios, y entonces en su llamarada como rosas que el viento desmenuza se romperán las hélices que cantan hacia los cielos la armonía última...

II

Lanzamos los aviones atravesando el día. En torno de los huesos nos envuelve una larga serpiente de ceniza.

Y aun cantamos en el horizonte... IOh cielos de amatista, mares de Dios, remansos de los mundos! ¡Nos mostrarás. Señor, todas tus islas!

$\mathrm{Y}$ en medio de huracanes, lejos, solo. como a través de ventanales lilas. pálido desde el fondo de los cielos para vernos morir viene el Mesias...

$\mathrm{Y}$ así como los ángeles giran en el viento de su nimbo vuelan hacia la muerte los aviones. El corazón se vuelca en un suspiro. 
$\mathrm{Y}$ nuestras voces en la maravilla se perfuman y elevan en un himno y van nuestros aviones estrechando la gloria de su círculo.

III

¡Cómo lucen las manos estrelladas del Cristo! Horizontes de seda abren las hélices. $\mathrm{Ya}$ empiezan a morir nuestros sentidos.

Dero aun en el viento de la muerte. en un canto suavísimo. nuestros aviones en la playa última vuelan en el aliento de un suspiro.

\section{IV}

Pero allí estás inmóvil, con las manos llagadas, triste el rostro. En ti suspira toda la Belleza. El universo se apoyó en fus hombros.

Miras los mundos; anclaron las estrellas en tus ojos y cuando alargas en tu cruz los brazos. llora tu corazón sobre los Polos.

Estamos cerca, cerca de la sangre florida de tus manos. Ya nuestro corazón es un recuerdo. En el aire de Dios va nuestro espanto.

Nada sentimos, nada.

Como en la paz de las praderas verdes el corazón se nos perfuma todo. ¡Acaso ya la eternidad lo envuelve! 
Callaron los aviones;

se durmieron las hélices.

Sólo veo tus manos frente al día.

¡Estás inmóvil siempre!

Sobre tu corazón cantan las horas;

giran los ángeles: las estrellas vienen

a tu colmena como las abejas.

IDime, Señor, si penetré en la muerte!...

ANGEL CRUCHAGA SANTA MARIA. 